\title{
Influential Polish publications in sedimentary geology 1996-2016
}

\author{
Grzegorz RACKI ${ }^{1, *}$ \\ 1 Silesian University, Department of Earth Sciences, Będzińska 60, PL-41-200 Sosnowiec, Poland
}

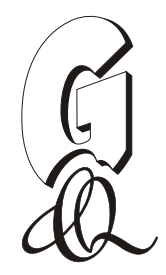

Racki, G., 2016. Influential Polish publications in sedimentary geology 1996-2016. Geological Quarterly, 60 (2): 537-546, doi: $10.7306 / g q .1298$

\begin{abstract}
The list of thirty highest cited recent Polish publications (after 1995) on diverse themes resulted from study of sedimentary rocks, usually referred as sedimentary geology, is presented. The progressively successful fields in Polish sedimentary research over the past 20 years include in first order large-scale palaeogeographic and lithofacies analyses in a broad geotectonic framework (by Golonka), and also tectonic-regional aspects of basin analysis, developed by several research groups in Cracow, Warsaw and Wrocław, in agreement with one of the leading research frontier in global science. Ecological and integrative stratigraphic-event characteristics of sedimentary successions are another well-known Polish areas of expertise, the best exemplified by flysch ichnology (Uchman) and Devonian studies at University of Silesia. Sedimentary geochemistry is still in infancy in Poland, despite a big progress in last years (in particular organic topics - Marynowski). The dominance of Cracow geological school is obvious, rooted in a long-lasting tradition of mostly Carpathian studies at Jagiellonian University since XIX century, even if the sedimentary research is well-advanced in many other institutions in Poland as well. For example, a newly emerging Polish specialty in tsunami hazard studies (Szczuciński) is notably located at Adam Mickiewicz University. Carpathian and post-Paleozoic stratigraphic-sedimentological themes were continuously the most popular, while an evolution toward effective cooperation in mostly international groups (also outside of Poland, especially in Ukraine) appears to be the most significant tendency in modern Polish geosciences.
\end{abstract}

Key words: Sedimentary geology, hot papers, citation analysis, Polish geology.

\section{INTRODUCTION}

The world-wide and multidisciplinary available online bibliographic databases with citation indexes, such as Web of Science (WoS) and Scopus, supplemented by Google Scholar (GS), are well-known as a powerful and reasonable tool for a research evaluation in result of comprehensive bibliometric studies (see extensive reviews in Garfield, 1979; Moed, 2005; Nowak, 2008; Marszakowa-Szajkiewicz, 2009; Drabek, 2010). One of the applications is discrimination of dynamic research frontiers in the particular disciplines (e.g., in climatology; Schwechheimer and Winterhager, 1999). In this cognitive context, the invited article focuses on the identification of the highest cited recent Polish publications (after 1995) for the closely linked geological topics involved in diverse study of sedimentary rocks, usually referred as sedimentary geology.

The research field is outlined herein very broadly due to the search limitation in the citation database, but such a loose definition well-corresponds to editorial approach of leading journal Sedimentary Geology ("all aspects of research into sediments and sedimentary rocks at all spatial and temporal scales"; http://www.journals.elsevier.com/sedimentary-geology/). Thus,

\section{*E-mail: racki@us.edu.pl}

Received: April 19, 2016; accepted: May 14, 2016; first published online: May 30, 2016 in contrast to previous sedimentology-based quantitative impact analysis of the global science (Middleton, 1974; Pikley and Pilcox, 1981; Racki, 2002), much more intergrading geoscience specialties (geology, physical geography, geophysics) have been covered herein, mostly linked with "geodynamic aspects of sedimentary-basin evolution" and "linkages between sedimentology and other earth systems, for example climate and biogeochemistry" (http://www.journals.elsevier.com/sedimentary-geology/). In the real case of Polish geology, as shown below, these most inluential fields include mostly palaeogeographic and tectonic aspects of basin analysis, as well as ecological characteristic of sedimentary successions (exemplified by ichnology), but not conventional sedimentological themes.

\section{METHODOLOGY}

In my previous articles on similar issue (Racki, 2002), the filtering search was simply limited to sedimentology articles from three core journals: Sedimentology, Sedimentary Geology (SG) and Journal of Sedimentary Research (JSR), nominated as the "Big Three" (compare Pilkey and Pilcox, 1981). In the Polish case, I have decided to undertake another survey of the literature with use of selected key words, because (1) the Polish contribution in the three journals is small (110 articles), and (2) the papers are relatively non-influential when compared with Polish contributions from other journals, even from Poland (see Ta- 
Highest cited Polish papers in sedimentary geology published over the 1996-2016 period (based on Scopus)

\begin{tabular}{|c|c|c|c|c|}
\hline Rank & Cited Paper & Authors & Source & $\begin{array}{l}\text { No. of } \\
\text { citations* }\end{array}$ \\
\hline 1 & $\begin{array}{l}\text { Plate tectonic evolution of the southern } \\
\text { margin of Eurasia in the Mesozoic and } \\
\text { Cenozoic }\end{array}$ & Golonka, J. (UJ) & $\begin{array}{l}\text { (2004) Tectonophysics, } \\
\text { 381: 235-273 }\end{array}$ & 312 \\
\hline 2 & $\begin{array}{l}\text { On the origin of the Southern Permian } \\
\text { Basin, Central Europe }\end{array}$ & $\begin{array}{l}\text { van Wees, J.-D. and } 9 \text { others, } \\
\text { including Dadlez, R. (PIG), } \\
\text { Narkiewicz, M. (PIG) } \\
\text { [NL, SE, DE] }\end{array}$ & $\begin{array}{l}\text { (2000) Marine and Petroleum } \\
\text { Geology, 17: 43-59 }\end{array}$ & 156 \\
\hline $3^{* *}$ & $\begin{array}{c}\text { Taxonomy and ethology of flysch trace } \\
\text { fossils: revision of the Marian } \\
\text { Ksia kiewicz collection and studies } \\
\text { of complementary material }\end{array}$ & Uchman, A. (UJ) & $\begin{array}{l}\text { (1998) Annales Societatis } \\
\text { Geologorum Poloniae, } \\
\text { 68: 105-218 }\end{array}$ & 144 \\
\hline $4^{* *}$ & $\begin{array}{c}\text { Ichnology of the Rhenodanubian Flysch } \\
\text { (Lower Cretaceous-Eocene) in Austria } \\
\text { and Germany }\end{array}$ & Uchman, A. (UJ) & (1999) Beringeria, 25: 67-173 & 142 \\
\hline 5 & $\begin{array}{c}\text { Palaeozoic amalgamation of Central } \\
\text { Europe: new results from recent } \\
\text { geological and geophysical investigations }\end{array}$ & $\begin{array}{l}\text { Winchester, J.A. and } 41 \text { others., } \\
\text { including: Guterch, A. (IG), Grad, M. } \\
\text { (UW), Cwojdziński, S. (PIG W), } \\
\text { Cymerman, Z. (PIG W), Kozdrój, W. } \\
\text { (PIG W), Kryza, R. (UWr), } \\
\text { Alexandrowski, P. (UWr), } \\
\text { Mazur, S. (UWr) } \\
\text { [UK, BE, DE, DK, FR, CZ] }\end{array}$ & $\begin{array}{l}\text { (2002) Tectonophysics, } \\
\text { 360: 5-21 }\end{array}$ & 134 \\
\hline 6 & $\begin{array}{l}\text { Pangean (Late Carboniferous-Middle Ju- } \\
\text { rassic) paleoenvironment and lithofacies }\end{array}$ & Golonka, J. (UJ), Ford, D. [US] & $\begin{array}{c}\text { (2000) Palaeogeography, } \\
\text { Palaeoclimatology, } \\
\text { Palaeoecology, 161:1-34 }\end{array}$ & 133 \\
\hline 7 & $\begin{array}{l}\text { Paleoreef maps: evaluation of a compre- } \\
\text { hensive database on Phanerozoic reefs }\end{array}$ & $\begin{array}{l}\text { Kiessling, W., Flügel, E., Golonka, J. (UJ) } \\
\text { [DE] }\end{array}$ & $\begin{array}{c}\text { (1999) AAPG Bulletin, } \\
\text { 83: } 1552-1587\end{array}$ & 128 \\
\hline 8 & $\begin{array}{c}\text { Late Vendian-Early Paleozoic tectonic } \\
\text { evolution of the Baltic Basin: regional } \\
\text { tectonic implications from subsidence } \\
\text { analysis }\end{array}$ & $\begin{array}{c}\text { Poprawa, } P \text {. }(\mathrm{PIG}) \text { and } 3 \text { others } \\
{[\mathrm{LV}, \mathrm{NL}]}\end{array}$ & $\begin{array}{l}\text { (1999) Tectonophysics, } \\
\text { 314: } 219-239\end{array}$ & 122 \\
\hline 9 & $\begin{array}{l}\text { Late Triassic and Early Jurassic } \\
\text { palaeogeography of the world }\end{array}$ & Golonka, J. (UJ) & $\begin{array}{c}\text { (2007) Palaeogeography, } \\
\text { Palaeoclimatology, } \\
\text { Palaeoecology, 244: 297-307 }\end{array}$ & 115 \\
\hline 10 & $\begin{array}{c}\text { Shelf-margin deltas: their stratigraphic } \\
\text { significance and relation to deepwater } \\
\text { sands }\end{array}$ & Porębski, S.J. (ING K), Steel, R.J. [US] & $\begin{array}{l}\text { (2003) Earth-Science } \\
\text { Reviews, 62: 283-326 }\end{array}$ & 115 \\
\hline 11 & $\begin{array}{l}\text { Climatically controlled terraces } \\
\text { in uplifting mountain areas }\end{array}$ & Starkel, L. [IGiPZ] & $\begin{array}{c}\text { (2003) Quaternary Science } \\
\text { Reviews, 22: 2189-2198 }\end{array}$ & 102 \\
\hline $12^{\star *}$ & Last Glacial Maximum in Poland & Marks, L. (PIG, UW) & $\begin{array}{c}\text { (2002) Quaternary Science } \\
\text { Reviews, 21: 103-110 }\end{array}$ & 102 \\
\hline 13 & $\begin{array}{c}\text { The Frasnian/Famennian boundary } \\
\text { interval in the South Polish-Moravian } \\
\text { shelf basins: integrated } \\
\text { event-stratigraphical approach }\end{array}$ & $\begin{array}{l}\text { Racki, G. (UŚ), Racka, M. (UŚ), } \\
\text { Matyja, H. (PIG), Devleeschouwer, X. [BE] }\end{array}$ & $\begin{array}{c}\text { (2002) Palaeogeography, } \\
\text { Palaeoclimatology, } \\
\text { Palaeoecology, 181: 251-297 }\end{array}$ & 101 \\
\hline $14^{\star *}$ & $\begin{array}{l}\text { Carpathian Foredeep Basin (Poland } \\
\text { and Ukraine) - its sedimentary, } \\
\text { structural and geodynamic evolution }\end{array}$ & $\begin{array}{l}\text { Oszczypko, N. (UJ), Krzywiec, P.(PIG), } \\
\text { Popadyuk, I., Peryt, T.M. (PIG) [UA] }\end{array}$ & $\begin{array}{l}\text { (2006) J. Golonka and F.J. } \\
\text { Picha (eds.). The Carpathians } \\
\text { and their foreland: geology } \\
\text { and hydrocarbon resources. } \\
\text { AAPG Memoir, 84: 293-350 }\end{array}$ & 100 \\
\hline 15 & $\begin{array}{l}\text { Were deforming subglacial beds beneath } \\
\text { past ice sheets really widespread? }\end{array}$ & $\begin{array}{c}\text { Piotrowski, J.A. and } 4 \text { others, including } \\
\text { Krzyszkowski, D. } \\
\text { (PU S) [DK, US, DE] }\end{array}$ & $\begin{array}{l}\text { (2001) Quaternary } \\
\text { International, 86: 139-150 }\end{array}$ & 95 \\
\hline 16 & $\begin{array}{c}\text { Extent and duration of marine anoxia } \\
\text { during the Frasnian-Famennian (Late } \\
\text { Devonian) mass extinction in Poland, } \\
\text { Germany, Austria and France }\end{array}$ & $\begin{array}{c}\text { Bond, D., Wignall, P.B., Racki, G. (UŚ) } \\
\text { [UK] }\end{array}$ & $\begin{array}{c}\text { (2004) Geological Magazine, } \\
\text { 141: 173-193 }\end{array}$ & 93 \\
\hline 17 & $\begin{array}{l}\text { Principal characteristics of the Upper } \\
\text { Silesian block and Małopolska block } \\
\text { border zone (southern Poland) }\end{array}$ & $\begin{array}{c}\text { Buła, Z. (PIG S), Jachowicz, M. } \\
\text { (PIG S), aba, J. (UŚ) }\end{array}$ & $\begin{array}{c}\text { (1997) Geological Magazine, } \\
\text { 134: 669-677 }\end{array}$ & 88 \\
\hline 18 & $\begin{array}{c}\text { Radiolarian palaeoecology and } \\
\text { radiolarites: is the present the key } \\
\text { to the past? }\end{array}$ & Racki, G. (UŚ), Cordey, F. [FR] & $\begin{array}{l}\text { (2000) Earth-Science } \\
\text { Reviews, 52: 83-120 }\end{array}$ & 86 \\
\hline \multirow{2}{*}{$\begin{array}{l}19- \\
20^{* *}\end{array}$} & $\begin{array}{l}\text { The Western Carpathian Foredeep - } \\
\text { development of the foreland basin } \\
\text { in front of the accretionary wedge } \\
\text { and its burial history (Poland) }\end{array}$ & Oszczypko, N. (UJ) & $\begin{array}{c}\text { (1998) Geologica Carpathica, } \\
\text { 49: 415-431 }\end{array}$ & 86 \\
\hline & $\begin{array}{c}\text { Palinspastic reconstruction } \\
\text { of the Carpathian-Pannonian region } \\
\text { during the Miocene }\end{array}$ & $\begin{array}{c}\text { Kováč, M. and } 7 \text { others, including } \\
\text { Oszczypko, N. (UJ), Slączka, A. (UJ) } \\
{[S K, H U, R O]}\end{array}$ & $\begin{array}{l}\text { (1998) Geodynamic } \\
\text { development of the Western } \\
\text { Carpathians (ed. M. Rakús): } \\
\text { 189-217. Geological Survey } \\
\text { of Slovak Republic, Bratislava }\end{array}$ & 86 \\
\hline
\end{tabular}


Tab. 1 cont

\begin{tabular}{|c|c|c|c|c|}
\hline Rank & Cited Paper & Authors & Source & $\begin{array}{l}\text { No. of } \\
\text { citations* }\end{array}$ \\
\hline 21 & Deltas and sea-level change & Porębski, S.J. (ING K), Steel, R.J. [US] & $\begin{array}{c}\text { (2006) Journal of Sedimentary } \\
\text { Research, 76: 390-403 }\end{array}$ & 82 \\
\hline 22 & $\begin{array}{l}\text { Sequential colonization of muddy } \\
\text { turbidites in the Eocene Beloveža } \\
\text { Formation, Carpathians, Poland }\end{array}$ & Wetzel, A., Uchman, A. (UJ) [CH] & $\begin{array}{c}\text { (2001) Palaeogeography, } \\
\text { Palaeoclimatology, } \\
\text { Palaeoecology, 168: 171-186 }\end{array}$ & 80 \\
\hline $23^{* *}$ & $\begin{array}{l}\text { Environmental and geological impacts } \\
\text { of the } 26 \text { December } 2004 \text { tsunami } \\
\text { in coastal zone of Thailand - overview } \\
\text { of short and long-term effects }\end{array}$ & $\begin{array}{l}\text { Szczuciński, W. (UAM) and } 7 \text { others, } \\
\text { including Niedzielski, P., Rachlewicz, } \\
\text { G., Lorenc, S., Siepak, J. (UAM) [TH] }\end{array}$ & $\begin{array}{c}\text { (2006) Polish Journal } \\
\text { of Environmental Studies, } \\
\text { 15: 793-810 }\end{array}$ & 78 \\
\hline $24^{\star *}$ & $\begin{array}{c}\text { Late Carboniferous-Neogene } \\
\text { geodynamic evolution and } \\
\text { paleogeography of the } \\
\text { circum-Carpathian region } \\
\text { and adjacent areas }\end{array}$ & $\begin{array}{c}\text { Golonk̦a, J., Oszczypko, N., } \\
\text { Slączka, A. (UJ) }\end{array}$ & $\begin{array}{l}\text { (2000) Annales Societatis } \\
\text { Geologorum Poloniae } \\
\text { 70: } 107-136\end{array}$ & 78 \\
\hline 25 & $\begin{array}{l}\text { Upper Cretaceous oceanic red beds } \\
\text { (CORBs) in the Tethys: occurrences, } \\
\text { lithofacies, age, and environments }\end{array}$ & $\begin{array}{c}\mathrm{Hu}, \mathrm{X} \text {. and } 7 \text { others, including Bąk, K. } \\
\text { [UP K] [CN, CA, IT, AT, SI] }\end{array}$ & $\begin{array}{c}\text { (2005) Cretaceous Research, } \\
\text { 26: 3-20. }\end{array}$ & 77 \\
\hline 26 & $\begin{array}{c}\text { Sand veins and wedges in cold aeolian } \\
\text { environments }\end{array}$ & $\begin{array}{c}\text { Murton, J.B., Worsley, P., Goździk, J. } \\
\text { (UŁ) [UK) }\end{array}$ & $\begin{array}{l}\text { (2000) Quaternary Science } \\
\text { Reviews, 19: 899-922 }\end{array}$ & 73 \\
\hline 27 & $\begin{array}{c}\text { Weathering mantles and their } \\
\text { significance for geomorphological } \\
\text { evolution of Central and Northern Europe } \\
\text { since the Mesozoic }\end{array}$ & Migoń, P. (UWr), Lidmar-Bergström, K. & $\begin{array}{l}\text { (2001) Earth-Science } \\
\text { Reviews, 56: 285-324 }\end{array}$ & 72 \\
\hline \multirow{2}{*}{$\begin{array}{l}28^{* *}- \\
29\end{array}$} & $\begin{array}{l}\text { Middle Triassic evolution of the northern } \\
\text { Peri-Tethys area as influenced by early } \\
\text { opening of the Tethys Ocean }\end{array}$ & Szulc, J. (UJ) & $\begin{array}{l}\text { (2000) Annales Societatis } \\
\text { Geologorum Poloniae, } \\
70: 1-48\end{array}$ & 72 \\
\hline & $\begin{array}{c}\text { The morphodynamics of fluvial sand dunes } \\
\text { in the River Rhine, near Mainz, Germany. } \\
\text { I. Sedimentology and morphology }\end{array}$ & $\begin{array}{l}\text { Carling, P.A., Gölz, E., Orr, H.G., } \\
\text { Radecki-Pawlik, A. (AU K) [UK, DE] }\end{array}$ & $\begin{array}{l}\text { (2000) Sedimentology } \\
47: 227-252\end{array}$ & 72 \\
\hline 30 & $\begin{array}{l}\text { Cyanobacterial calcification and its } \\
\text { rock-building potential during } 3.5 \text { billion } \\
\text { years of Earth history }\end{array}$ & $\begin{array}{c}\text { Altermann, W., Kaźmierczak, J. (IP), } \\
\text { Oren, A., Wright, D. } \\
\text { [SE, IL, UK] }\end{array}$ & $\begin{array}{c}\text { (2006) Geobiology } \\
\text { 4: 147-166. }\end{array}$ & 71 \\
\hline
\end{tabular}

* Classified according to total citation numbers (jointly with self-citations), followed by "article age" (younger papers ranked higher); ** publications added in result of individual quest

Institutional affiliation of Polish authors:

Polish Academy of Sciences (PAN): IGiPZ - Institute of Geography and Spatial Organization, Cracow; ING - Institute of Geological Sciences, Cracow (K); IP - Institute of Paleobiology; Warsaw, IG - Institute of Geophysics, Warsaw.

UW - University of Warsaw; UWr - University of Wrocław; UJ - Jagiellonian University in Cracow; UAM - Adam Mickiewicz University in Poznań; UŁ - University of Łódź; UŚ - University of Silesia in Katowice, Earth Sciences Faculty in Sosnowiec; UP K - Cracow Pedagogical University; PU S - Pomeranian University in Słupsk; Au K - Agricultural University in Cracow.

PIG - Polish Geological Institute - National Research Institute, Warsaw (W - Lower Silesian Branch in Wrocław; S - Upper Silesian Branch in Sosnowiec).

Country code of foreign coworkers: US - USA, UK - Great Britain, DE - Germany, FR - France, IT- Italy, CA - Canada, CH - Switzerland, AT - Austria, SE - Sweden, NL - Netherland, BL - Belgium, DK - Denmark, UA - Ukraine, SV - Slovakia, CZ - Czech Rp., SI - Slovenia, HU - Hungary, RO - Romania, LV - Lithuania, IL - Israel, CN - China, TH - Thailand

ble 1). For example, the most cited paper from SG is outside this top thirty rating (Szulczewski et al., 1996, 62 cites).

I have discussed different search constrains and subjectivity of complex methodology in any attempt to select papers from the rapidly expanding, more and more interdisciplinary research area (Racki, 2002). Again, the rankings presented below are likely an incomplete collection of the "hot" articles and themes in recent Polish literature, partly intuitively selected within the continuous thematic gradation of evolving geoscience, but I believe in their overall representative status.

The Elsevier's citation database Scopus appears far friendlier to realize this survey than the celebrated WoS. What more, Scopus covers more numerous set of registered sources, and also 30 Polish geoscience periodicals (partly in Polish only) in subject area Earth and Planetary Sciences (http://www.scima- gojr.com/journalrank.php?area $=1900 \&$ category $=0 \&$ country $=P L$ \&year=2014\&order=t\&min=0\&min_type $=c d$ ). Thus, domesticregional aspects are better represented in the list of highest cited references, rather than a reception of these results by international geologic community, exposed in WoS. The sources are regularly indexed after 1995 and therefore this research is constrained to the last 20 years.

To find Polish papers in the broadly-outlined area of sedimentary geology, four-step filtering quest has been used:

1. Search by the selected key word alternative combination in title, abstract and keywords, linked with request of Polish affiliation [(TITLE-ABS-KEY (sediment $\left.{ }^{*}\right)$ OR TITLE-ABS-KEY (lithofacies) OR TITLE-ABS-KEY (facies) AND AFFILCOUNTRY (poland)) AND PUBYEAR > 1995] 
In effect, 6,574 document results contain papers with at least one of the words: sediment(s), sedimentary, sedimentation, sedimentology, facies or lithofacies in their title or abstract or key words. Use of extra terms (e.g., deposit* or litho*) has led rather to more information noise than further important data, due to increased inset of geophysical papers.

2. The paper selection was limited to subject area Earth and Planetary Sciences, what reduced its size to 3,965 document results after exclusion of papers assigned exclusively to Environmental Science, Agricultural and Biological Sciences, Medicine, Chemistry, etc.

3. Furthermore, the remained array was reduced to 3,187 , when interdisciplinary papers are rejected, i.e., still referred to Agricultural and Biological Sciences (511 documents) and Environmental Science (361) as well. The second elimination could be in fact controversial, but a decisive argument resulted from the fact that the recognized highly-cited papers, related with this discipline, were conducted in non-geological institutions [see examples below].

4. From the geosciences paper set were lastly excluded these with key word "Metamorphism" (52), incorporated mostly to this document pool due to presence of the phrase "metamorphic facies" or "granulite facies".

Representativeness of the final array, comprising 3,135 documents, was tested by examination how many Polish papers from the the Big Three core were included. Because above 78\% articles has been discovered by this search procedure, the filtering effect is overall satisfactory, though this refers in fact only to the papers from Sedimentary Geology (66 from 72).

However, to compensate the key weaknesses, this raw ranking was more or less subjectively modified in two ways:

1. To retrieve hot papers from the hitherto omitted part of literature (ca. $20 \%$ ?), a supplementary survey was performed individually for the most important journals and authors after examination of lists revealed in the obtained documents set (see section REMARKS ON SEDIMENTARY RESEARCH IN POLAND), in the latter case including also sources not registered in Scopus (via search option "View secondary documents"). Thus, 8 additional papers are introduced to the final ranking.

2. Simultaneously, the negative selection scoped on $11 \mathrm{pa}-$ pers of the originally-produced list that are most distant thematically from the core of sedimentary geology in more traditional meaning. This intuitive operation was exclusively on the Author responsibility. The following research fields are removed:

- Seismic crust structure: highly cited geophysical-geological papers by Warsaw group headed by Guterch and Grad, largely in Tectonophysics, such as by Guterch et al. (1999, 147 cites).

- Geochronology and correlation of Pleistocene successions (Litt et al., 2001, 193 cites), including Holocene hydrological events in fluvial record (e.g., Macklin et al., $2006,172)$ and methodology of luminescence dating (Singhvi et al., 2001, 95).

- Metamorphic geology: still preserved in the filtered suite, articles of Dubińska et al. $(2004,113)$ and Kryza et al. (1996, 103).

- Geochemical-environmental aspects of recent sediments (e.g., metal contamination) and/or soil analyses from the environmental science domain: affiliated with non-geological (i.e., medical or agricultural) institutions, such as highly prosperous papers of Loska and Wiechuła (2003) in Chemosphere (265 cites) and Mench et al. (2010) in Journal of Soils and Sediments (101).

- Clay mineralogy: review article of the widely-known Polish expert - Środoń (1999, 115 cites).
- Tectonically - "biased" papers, represented by the most cited article from Geological Quarterly on the Polish Variscan basin by Mazur et al. (2006, 137 cites), as well as the contribution to Sudetic terrane geology by Cymerman et al. (1997, 93).

On the other hand, some papers focused on biochronostratigraphic aspects (Kennedy et al., 2000, 89 cites) or microbial geobiology of carbonates (Benzerara et al., 2006, 106 cites) are noteworthy, but likewise not added to the ranking list.

The last and surely objective criterion was a minimal range of the Polish author participation in the multi-authored papers that should exceed $10 \%$. Consequently, for example, the up-to-date trace fossil revision by Bertling et al. (2006, 11 co-authors including Uchman, 168 cites) is disqualified, as well as new data on the last deglaciation from Science (Rinterknecht et al., 2006, 12 co-authors together with Marks, 131 cites). Noteworthy, author self-citations are included in the counts, and therefore the statistics, gathered to 1st April 2016, display in part also the author publication activity, coupled with continuity and unwarranted visibility of some subjects in vogue in the literature.

\section{HIGHEST CITED POLISH PAPERS AND THEMES}

At the top of the citation rating (312 cites; see Table 1) is the outstanding palaeogeographic synopsis by Golonka from 2004 in Tectonophysics, on Meso-Cenozoic plate tectonic evolution of the southern margin of Eurasia, visualized on thirteen time interval maps, which depict the plate tectonic configuration, palaeogeography and general lithofacies pattern. The prominently influential contribution reflects a far-reaching geodynamic linkage between generalized facies analysis and large-scale tectonic evolution within a global framework. This citation effectivity of the worldwide authority from Cracow is confirmed by presence of his five articles in the citation rating.

On the whole, more or less related motives of geodynamically-driven sedimentary basin development, paired with subsidence evolution and regional tectonic implications, based partly on integrated geological and geophysical works, predominate in different varieties in the 13 highlighted papers, and eight of them is included in the top ten positions. The thematic set seems to be Polish area of expertise in the recent broadly-outlined sedimentary geology, as shown by both supra-regional and worldwide reconstructions by Golonka, as well as different-scale regional studies. This research frontier in modern Polish sedimentary geology is perfectly exemplified especially by four Oszczypko's contributions to understanding of the Carpathian geotectonic domain, even if all placed in the lower half of list. On the other hand, the highest cited papers include multi-authored international work on the origin of Permian Central European basin by van Wees et al. (2000; in Marine and Petroleum Geology), with participation of Dadlez and Narkiewicz (2nd rank, 156 cites).

Another Polish achievement in the continuously increasing "competition for attention" (Franck, 1999) comprises ichnological works of Uchman, the most actively publishing Polish author (see below), scoped on flysch environments ( 3 articles on the list). The classical sedimentological issues are presented especially comprehensively in two papers on deltas co-authored by Porębski, but also in fluvial sand dunes study (Radecki-Pawlik), and Quaternary glacial and aeolian deposition aspects (Marks, Krzyszkowski, Goździk), as well as climatically controlled terrace origin (Starkel). The identified environ- 
mental and processes spectrum of 30 hot articles is not obviously extensive. Besides the dominating siliciclastic topics, also red oceanic (Bąk) and biosiliceous (Racki) facies are represented, as well as carbonates shown in dynamical palaeogeographic (Szulc), integrative event-stratigraphic (Racki et al.) and geobiological/cyanobacterial (Kaźmierczak) contexts.

Importantly, among recentmost papers in WoS, nominated as "Highly Cited Paper", is the contribution by Szczucińsk (2012) in Natural Hazards on post-depositional changes of the onshore 2004 tsunamite in the Andaman Sea, that received already 58 cites (67 in Scopus). With average citation rate 15 per year, this is a rising star of Polish sedimentological literature. If we consider the participation of this author in another very hot collective paper (11 authors) of Goto et al. (2011, 98 cites), a newly emerging Polish specialty, located at the Adam Mickiewicz University, becomes obvious, in addition to very active group in Quaternary sedimentology led by Zieliński (see below).

In addition to the most numerous (18) contributions from several Cracow institutions (apparently connected with a long-lasting tradition of sedimentological studies in Jagiellonian University; see below data on prosperous Dzułyński's works), the authors of other well-known publications work also in cities less renowned from this viewpoint, such as Sosnowiec (4), Wrocław (3), Poznań (1), Łódź (1) and Słupsk (1). As usually, stimulating effect of international cooperation is well-visible in the widely explored modern fields of study, but 10 papers are authored only by Polish geologists and geographers. Also presence of four articles from Polish journals (three from the Cracow periodical of the Polish Geological Society) is noteworthy as well. However, the best visible in the rating is the Elsevier multidisciplinary medium Palaeogeography, Palaeoclimatology, Palaeoecology (4 papers), as well as Tectonophysics (3 high-rated articled), Earth-Science Reviews (3 review articles) and Quaternary Science Reviews (3 review articles).

\section{LIVING OLDER PAPERS}

A list of older, published before 1996, invariably significant publications (quoted in the narrowed time window 2006-2016; Table 2), is even more subjective but exposes several interesting characters concerning an evolution of Polish geology. The thematic dispersion of these still living articles is broader, and the palaeogeographic-tectonic motifs are represented only by two multi-authored papers from early 1990s, the both with Dadlez as the first author. At the highest top of the citation rating is an outstanding paper of Uchman from 1995 on taxonomy and ecology of Italian flysch trace fossils.

In the chronological context, a true phenomenon are consistently well-known, classic sedimentological works of D ułyński, especially popular in the Internet sources, as revealed by high quotation numbers by all-embracing Google Scholar statistics. The classic experimental 1970 paper on systems with reversed density gradients (Anketell et al.) is a continuous inspiration also for present scholars. As another impressive instance, the article by $\mathrm{D}$ ułyński, Ksią kiewicz and Kuenen on the Carpathian turbitites, published in 1959 in Bulletin of the Geological Society of America, achieved 238 quotations in the

Table 2

Twelve selected high-cited Polish papers in sedimentary geology in 2005-2016, published prior to 1996 (based on Scopus)

\begin{tabular}{|c|c|c|c|}
\hline Cited Paper & Authors & Source & $\begin{array}{c}\text { No. of } \\
\text { citations }\end{array}$ \\
\hline $\begin{array}{l}\text { Taxonomy and palaeoecology of flysch trace fossils: the } \\
\text { Marnoso-arenacea Formation and associated } \\
\text { facies (Miocene, Northern Apennines, Italy) }\end{array}$ & Uchman, A. & (1995) Beringeria, 15: 1-115 & $182(269)$ \\
\hline $\begin{array}{c}\text { Largest known microbialites discovered } \\
\text { in Lake Van, Turkey }\end{array}$ & $\begin{array}{c}\text { Kempe, S., Kaźmierczak, J. } \\
\text { and } 4 \text { others }\end{array}$ & (1991) Nature, 349: 605-608 & $81(129)$ \\
\hline $\begin{array}{c}\text { Tectonic evolution of the Mid-Polish Trough: } \\
\text { modelling implications and significance for central } \\
\text { European geology }\end{array}$ & $\begin{array}{l}\text { Dadlez, R., Narkiewicz, M., } \\
\text { Stephenson, R.A., Visser, } \\
\text { M.T.M., van Wees, J.-D. }\end{array}$ & $\begin{array}{l}\text { (1995) Tectonophysics, } \\
\text { 252: } 179-195\end{array}$ & $79(149)$ \\
\hline $\begin{array}{c}\text { Some key problems of the pre-Permian tectonics } \\
\text { of Poland }\end{array}$ & $\begin{array}{l}\text { Dadlez, R., Kowalczewski, } \\
\text { Z., Znosko, J. }\end{array}$ & $\begin{array}{l}\text { (1994) Kwartalnik Geologiczny/ } \\
\text { Geological Quarterly, } \\
\text { 38: 169-189 }\end{array}$ & $75(141)$ \\
\hline $\begin{array}{c}\text { Evolution of the bank to reef complex in the Devonian } \\
\text { of the Holy Cross Mountains }\end{array}$ & Racki, G. & $\begin{array}{l}\text { (1993) Acta Palaeontologica } \\
\text { Polonica, 37: 87-182 }\end{array}$ & $68(124)$ \\
\hline $\begin{array}{l}\text { On the deformational structures in systems } \\
\text { with reversed density gradients }\end{array}$ & $\begin{array}{l}\text { Anketell, J.M., Cegła, J., } \\
\text { D ułyński, S. }\end{array}$ & $\begin{array}{c}\text { (1970) Rocznik Polskiego } \\
\text { Towarzystwa Geologicznego, } \\
\text { 40: } 3-30\end{array}$ & $\begin{array}{l}65(153 ; \\
\text { GS - } 256)\end{array}$ \\
\hline $\begin{array}{l}\text { Depositional evolution of the Holy Cross Mts. (Poland) } \\
\text { in the Devonian and Carboniferous - a review }\end{array}$ & Szulczewski, M & $\begin{array}{l}\text { (1995) Kwartalnik Geologiczny/ } \\
\text { Geological Quarterly, } \\
\text { 39: 471-488 }\end{array}$ & $62(102)$ \\
\hline $\begin{array}{l}\text { Turonian through Santonian deposits of the Central } \\
\text { Polish Uplands; their facies development, inoceramid } \\
\text { paleontology and stratigraphy }\end{array}$ & Walaszczyk, I. & $\begin{array}{l}\text { (1992) Acta Geologica Polonica, } \\
42: 1-122\end{array}$ & $58(102)$ \\
\hline Glacigenic Sediments & $\begin{array}{l}\text { Brodzikowski, K., } \\
\text { van Loon, A.J. }\end{array}$ & $\begin{array}{l}\text { (1991) Developments in } \\
\text { Sedimentology, 49: } 1-673 . \\
\text { Elsevier, Amsterdam }\end{array}$ & $55(98)$ \\
\hline $\begin{array}{l}\text { Upper Devonian conodonts, stratigraphy and facial } \\
\text { development in the Holy Cross Mts }\end{array}$ & Szulczewski, M. & $\begin{array}{l}\text { (1971) Acta Geologica Polonica, } \\
21: 1-129\end{array}$ & $53(115)$ \\
\hline $\begin{array}{c}\text { The role of alkalinity in the evolution of ocean chemistry, } \\
\text { organization of living systems, and biocalcification } \\
\text { processes }\end{array}$ & Kempe, S., Kaźmierczak, J. & $\begin{array}{c}\text { (1994) Bulletin de l'Institut } \\
\text { Océanographique (Monaco), } \\
\text { 13: } 61-117\end{array}$ & $50(94)$ \\
\hline Sedimentary Features of Flysch and Greywackes & D ułyński, S., Walton, E.K. & $\begin{array}{l}\text { (1965) Developments in } \\
\text { Sedimentology, 7: } 1-274 . \\
\text { Elsevier, Amsterdam }\end{array}$ & $\begin{array}{l}47 \text { (125; } \\
\text { GS - 397] }\end{array}$ \\
\hline
\end{tabular}


Internet-recognized sources, but only 36 times in Scopus. This is good occasion to recall the similarly aged classical paper on Holy Cross Cambrian trilobite ichnocoenosis by Radwański and Roniewicz (1963, 32 citations in Scopus, 49 in GS).

Other distinguishing features of the list are (1) common presence of single-authored papers, paired with (2) articles from largely Polish journals (six papers). This is a record of the past times pre-dating modern tendency toward growing international cooperation in interdisciplinary research groups (see Table 1), already well expressed by the review article from 1994 of Krajewski and ten foreign co-authors on sedimentary apatite formation (66 recent cites).

\section{A BRIEF INSIGHT INTO THE WORLDWIDE SCIENCE}

For a comparison, the main developmental tendencies are briefly noted in the worldwide geology. As discernable in the hot paper array within 124,743 paper dataset from 1996-2016, selected according to the same rough, four-step filtering search procedure described above for the Polish sedimentary geology (nota bene, the leading Golonka's paper takes 175th rank). After exclusion of common non-geological (in the Author understanding), mostly purely geochemical/environmental (e.g., Budzinski et al., 1997, 642 cites) and tectonic contributions, the more evident leading themes in sedimentary research, that received more than 500 cites, may be summarized as follows (see Table 3; compare Racki, 2002):

- Palaeogeography - and facies-oriented geotectonic issues are frequent in the document selection, although the most influential papers refer to complex Precambrian issues. The representative examples are headed by Chinese scholars: modern (2008) presentation the history of supercontinent Rodinia (Li et al.), and an integrative interpretation of North China Archean blocks (Zhao et al.). Thus, the most advanced Polish field in recent sedimentary geology overall well-corresponds with this progressive research frontier.

- Sedimentary geochemical themes are even more up to date, and cover a broad diversity of organic, inorganic and isotope themes. Two highest-rated examples include

Table 3

Seventeen selected high-cited papers in sedimentary geology published over the 1996-2016 period (based on Scopus)

\begin{tabular}{|c|c|c|c|}
\hline Cited Paper & Authors & Source & $\begin{array}{c}\text { No. of } \\
\text { citations* }\end{array}$ \\
\hline $\begin{array}{l}\text { The chemical composition of subducting sediment } \\
\text { and its consequences for the crust and mantle }\end{array}$ & Plank, T., Langmuir, C.H. & $\begin{array}{c}\text { (1998) Chemical Geology, 145: } \\
\text { 325-394 }\end{array}$ & 1375 \\
\hline $\begin{array}{c}{ }^{87} \mathrm{Sr} /{ }^{86} \mathrm{Sr}, \delta^{13} \mathrm{C} \text { and } \delta^{18} \mathrm{O} \text { evolution of Phanerozoic } \\
\text { seawater }\end{array}$ & Veizer, J. and 14 others & (1999) Chemical Geology, 161: 59-88 & 1157 \\
\hline The physics of debris flows & Iverson, R.M. & $\begin{array}{l}\text { (1997) Reviews of Geophysics, } \\
\text { 35: 245-296 }\end{array}$ & 1098 \\
\hline $\begin{array}{c}\text { Assembly, configuration, and break-up history } \\
\text { of Rodinia: a synthesis }\end{array}$ & Li, Z.X. and 16 others & $\begin{array}{c}\text { (2008) Precambrian Research, } \\
\text { 160: 179-210 }\end{array}$ & 967 \\
\hline $\begin{array}{c}\text { Environmental characterization of global sources of } \\
\text { atmospheric soil dust identified with the Nimbus } 7 \\
\text { Total Ozone Mapping Spectrometer (TOMS) } \\
\text { absorbing aerosol product }\end{array}$ & $\begin{array}{l}\text { Prospero, J.M., Ginoux, P., } \\
\text { Torres, O., Nicholson, S.E., } \\
\text { Gill, T.E., }\end{array}$ & $\begin{array}{l}\text { (2002) Reviews of Geophysics, } \\
\text { 40: 2-1-2-31 }\end{array}$ & 965 \\
\hline $\begin{array}{l}\text { Archean blocks and their boundaries in the North } \\
\text { China Craton: lithological, geochemical, structural } \\
\text { and P-T path constraints and tectonic evolution }\end{array}$ & $\begin{array}{l}\text { Zhao, G., Wilde, S.A., } \\
\text { Cawood, P.A., Sun, M. }\end{array}$ & $\begin{array}{l}\text { (2007) Precambrian Research, } \\
\text { 107: 45-73 }\end{array}$ & 862 \\
\hline $\begin{array}{l}\text { Gradistat: a grain size distribution and statistics } \\
\text { package for the analysis of unconsolidated } \\
\text { sediments }\end{array}$ & Blott, S.J., Pye, K. & $\begin{array}{l}\text { (2001) Earth Surface Processes and } \\
\text { Landforms, 26: 1237-1248 }\end{array}$ & 858 \\
\hline $\begin{array}{c}\text { Organic geochemical proxies of paleoceanographic, } \\
\text { paleolimnologic, and paleoclimatic processes }\end{array}$ & Meyers, P.A. & $\begin{array}{l}\text { (1997) Organic Geochemistry, } \\
\text { 27: 213-250 }\end{array}$ & 754 \\
\hline $\begin{array}{c}\text { The snowball Earth hypothesis: testing the limits } \\
\text { of global change }\end{array}$ & Hoffman, P.F., Schrag, D.P. & (2002) Terra Nova, 14: 129-155 & 719 \\
\hline $\begin{array}{c}\text { Geocarb III: a revised model of atmospheric } \mathrm{CO}_{2} \\
\text { over Phanerozoic time }\end{array}$ & Berner, R.A., Kothavala, Z. & $\begin{array}{c}\text { (2001) American Journal of Science, } \\
\text { 301: 182-204 }\end{array}$ & 677 \\
\hline Foreland basin systems & DeCelles, P.G., Giles, K.A., & (1996) Basin Research, 8: 105-123 & 662 \\
\hline Late Quaternary ice sheet history of northern Eurasia & $\begin{array}{l}\text { Svendsen, J.I. and } \\
29 \text { others }\end{array}$ & $\begin{array}{c}\text { (2004) Quaternary Science Reviews, } \\
\text { 23: 229-1271 }\end{array}$ & 650 \\
\hline $\begin{array}{c}\text { What happens to terrestrial organic matter } \\
\text { in the ocean? }\end{array}$ & $\begin{array}{l}\text { Hedges, J.I., Keil, R.G., } \\
\text { Benner, R. }\end{array}$ & $\begin{array}{c}\text { (1997) Organic Geochemistry, } \\
\text { 27: 195-212 }\end{array}$ & 643 \\
\hline $\begin{array}{l}\text { The physical character of subaqueous sedimentary } \\
\text { density flow and their deposits }\end{array}$ & Mulder, T., Alexander, J. & (2001) Sedimentology, 48: 269-299 & 623 \\
\hline $\begin{array}{l}\text { Microbial carbonates: the geological record } \\
\text { of calcified bacterial-algal mats and biofilms }\end{array}$ & Riding, $\mathrm{R}$. & $\begin{array}{c}\text { (2000) Sedimentology, } 47 \text { (Suppl. 1): } \\
\text { 179-214 }\end{array}$ & 619 \\
\hline $\begin{array}{c}\text { Morphology, genesis, and distribution } \\
\text { of nanometer-scale pores in siliceous mudstones } \\
\text { of the Mississippian Barnett Shale }\end{array}$ & $\begin{array}{l}\text { Loucks, R.G., Reed, R.M., } \\
\text { Ruppel, S.C., Jarvie, D.M. }\end{array}$ & $\begin{array}{l}\text { (2009) Journal of Sedimentary Re- } \\
\text { search, 79: 848-861 }\end{array}$ & 542 \\
\hline $\begin{array}{c}\text { Trace metals as paleoredox } \\
\text { and paleoproductivity proxies: an update }\end{array}$ & $\begin{array}{l}\text { Tribovillard, N., Algeo, T.J., } \\
\text { Lyons, T., Riboulleau, A. }\end{array}$ & (2006) Chemical Geology 232: 12-32 & 530 \\
\hline
\end{tabular}


works of Plank and Langmuir (1375 cites!) on chemical composition of subducting sediments, and Veizer et al. concerning isotopic evolution of Phanerozoic sea water, supplemented by Meyer's review article who summarized organic geochemical proxies of oceanographic, limnologic, and climatic processes. In addition, evidently also useful is an updated summary of trace metals as redox and bioproductivity proxies by Tribovillard et al.

Also sophisticated numerical simulations of Earth system history are very persuasive and sophisticated motifs in recent geosciences, even if more and more distant from real geological work, such as the revised model of the Phanerozoic evolution of the atmospheric $\mathrm{CO}_{2}$ (Berner and Kothavala), and testing of the modern snowball Earth scenario (Hoffman and Schrag).

The geochemical area is poorly represented on the Polish list (Racki et al., 2002; but see also e.g., Joachimski et al., 2001; 124 cites), but this approach to sedimentary record is far more abundantly present in later publications. For example, Marynowski's publication activity (see Table 5) is the best signature of expansive sedimentary-organic topics (e.g., on the forest fire record - Marynowski and Simoneit, 2009, 55 cites). Thus, the most advanced research group is presently at University of Silesia.

- More conventional results in sedimentology-related frontier include a geophysical foundation of debris flow processes (Iverson; cf. also Mulder and Alexander), application of the satellite to detect the global pattern of major atmospheric dust sources (Prospero et al.) and computer program for the quick granulometric analysis (Blott and Pye). Also a comprehensive review of foreland basin system by DeCelles and Giles remains a notable contribution, as well as study on the transport and fate of land-derived organic matter in the oceanic settings (Hedges et al.).

From the Big Three journals, two review-methodological articles from Sedimentology are most successful, concerning subaqueous sedimentary density flows (Mulder and Alexander) and microbially-induced carbonates (Riding) - the latter still challenged question is fruitfully reviewed later also by Dupraz et al. (2009, 322 cites). The hottest and noteworthy very short-living article from JSR concerns nanometre-scale porosity in Car- boniferous siliceous mudstones (Loucks et al., 542 cites), whilst the leader of SG describes diagenetic sulfate reduction (Machel, 2001, 330 cites). The former theme certainly records the fever of gas-producing shale reservoirs. High in the worldwide classification is also another rising star among sedimentary articles with presentation of a new computer modelling of sedimentation processes for chronological records by Ramsey (2008, 479 cites). For comparison the citation impact, however, a comprehensive monograph of Miall (1996), The geology of fluvial deposits: sedimentary facies, basin analysis, and petroleum geology, was referenced 1429 times.

\section{REMARKS ON SEDIMENTARY RESEARCH IN POLAND}

The total collection of 3,135 works is granted as a source for some statistics (Tables 4-6) showing generally a situation of Polish sedimentary research over the last twenty years. Unquestionably, only a few crude generalisations are carefully presented, without any deepened consideration, what is dictated by partly uncertain or even biased nature of the covered research area (see above).

Between 1996 and 2015, the number of publications increased from 57 to 232 (in 2012), and doubled over XXI century. In the institutional rating, the top position is occupied by the Polish Geological Institute - National Research Institute, but this is a non-surprising achievement largely influenced by indexation of several large journals issued by this institute in Scopus (see Table 6). The next ranks occupy University of Warsaw (an joint achievement of geologists and geophysicians) and Jagiellonian University. Co-authorship with $\mathrm{Na}$ tional Academy of Sciences in Ukraine in 43 papers records the prolific collaboration, realized mostly by Polish Geological Institute - National Research Institute (see below).

With the distinctive front-runner, Uchman from Jagiellonian University, other most actively publishing authors are from Cracow (e.g., Oszczypko) and Warsaw (Peryt, also e.g., Grad, Krzywiec; Table 5). Likewise, three geologists from Sosnowiec (Marynowski, Racki, Zatoń) are present in the top ten rating, whilst Wysocka exemplifies the geological school at University of Warsaw. However, when 149 papers from five strictly

Table 4

Main centers of broadly-defined sedimentary research (and sedimentology) in Poland 1996-2016

\begin{tabular}{|l|c|c|}
\hline \multicolumn{1}{|c|}{ Institution } & City & No. of papers \\
\hline Polish Geological Institute - National Research Institute & Warsaw & $668(24)$ \\
\hline University of Warsaw & Warsaw & $348(18)$ \\
\hline Jagiellonian University & Cracow & $304(23)$ \\
\hline AGH University of Science and Technology & Cracow & $290(9)$ \\
\hline Adam Mickiewicz University & Poznań & $274(32)$ \\
\hline University of Silesia & Sosnowiec & $261(17)$ \\
\hline Institute of Geological Sciences of the of the Polish Academy of Sciences & Warsaw* & $242(13)$ \\
\hline University of Wrocław & Wrocław & $204(2)$ \\
\hline Institute of Paleobiology of the Polish Academy of Sciences & Warsaw & $108(13)$ \\
\hline Maria Curie-Skłodowska University & Lublin & $89(4)$ \\
\hline
\end{tabular}

*With regional branches/research centres in other cities (see Table 1); no. of papers italicized is total number of publications in five strictly sedimentological periodicals (The Big Three, Facies, Developments in Sedimentology) 
Most active Polish authors in the broadly-defined sedimentary research 1996-2016

\begin{tabular}{|l|c|c|}
\hline \multicolumn{1}{|c|}{ Author } & Affiliation & No. of papers \\
\hline Uchman, A. & Jagiellonian University & $84(11)$ \\
\hline Peryt, T.M. & Polish Geological Institute - National Research Institute & $43(12)$ \\
\hline Marynowski, L. & University of Silesia & $34(4)$ \\
\hline Oszczypko, N. & Jagiellonian University & $33(0)$ \\
\hline Grad, M. & University of Warsaw & $33(0)$ \\
\hline Krzywiec, P. & $\begin{array}{l}\text { Polish Geological Institute - National Research Institute } \\
\text { (now - Institute of Geological Sciences PAS in Warsaw) }\end{array}$ & $32(0)$ \\
\hline Narkiewicz, M. & Polish Geological Institute - National Research Institute & $29(3)$ \\
\hline Wysocka, A. & University of Warsaw & $28(0)$ \\
\hline Racki, G. & Uniwersity of Silesia & $27(1)$ \\
\hline Zatoń, M. & Uniwersity of Silesia & $26(4)$ \\
\hline
\end{tabular}

No. of papers italicized is total number of publications in five strictly sedimentological periodicals (The Big Three, Facies, Developments in Sedimentology)

Most popular journals in the Polish sedimentary research 1996-2016

\begin{tabular}{|c|c|c|}
\hline Source title & Publisher & No. of papers \\
\hline \multicolumn{3}{|c|}{ Polish journals } \\
\hline Przegląd Geologiczny (P) & Polish Geological Institute - National Research Institute & 442 \\
\hline Geological Quarterly/Kwartalnik Geologiczny & Polish Geological Institute - National Research Institute & 297 \\
\hline Biuletyn Państwowego Instytutu Geologicznego (P) & Polish Geological Institute - National Research Institute & 205 \\
\hline Acta Geologica Polonica & Warsaw University - Polish Academy of Sciences & 107 \\
\hline Annales Societatis Geologorum Poloniae/Rocznik PTGeol & Polish Geological Society & 99 \\
\hline \multicolumn{3}{|c|}{$\begin{array}{ll} & \text { Foreign journals } \\
\end{array}$} \\
\hline Quaternary International & Elsevier & 89 \\
\hline Sedimentary Geology & Elsevier & 66 \\
\hline Geomorphology & Elsevier & 52 \\
\hline Geologica Carpathica & Slovak Academy of Sciences & 52 \\
\hline Tectonophysics & Elsevier & 40 \\
\hline
\end{tabular}

$\mathrm{P}$ - domestic periodicals published mostly in Polish

sedimentological source titles are only taken into consideration, the institution and author hierarchy is distinctly modified (Tables 4 and 5). A prominent role of the Quaternary research group with Zieliński, van Loon and Gruszka (formerly University of Silesia, presently Adam Mickiewicz University; jointly 25 publications) is particularly exposed.

The results appeared largely in publications of the Polish Geological Institute (Przegląd Geologiczny, followed by Geological Quarterly and Biuletyn Państwowego Instytutu Geologicznego; Table 6). In international context, the Elsevier journals highly predominate (led by Quaternary International and Sedimentary Geology), and only Slovak Geologia Carpathica, co-published with the Polish Geological Institute - National Research Institute, interrupts this supremacy. Facies (25 articles) and International Journal of Earth Sciences (24), both published by Springer, and Geological Magazine (Cambridge University, 19) are other more popular journals outside the Elsevier domain.

When looking at the most popular thematic topics in the analysed article selection, the high-rated key words contain: Paleoenvironment (252 papers), Sedimentation (245), Sedi- mentology (233) and Biostratigraphy (222)/Stratigraphy (208), whilst, for example, Tectonics (131), Geochemistry (124) and Paleoclimate (123). Thus, the various stratigraphic issues are still traditionally associated with the sedimentological works, and recently with a more focus on the upper half of stratigraphic table: Pleistocene (187), Miocene (184), Cretaceous (163), Holocene (162), versus Carboniferous (101), Devonian (96) and Silurian (50). Regionally, the studies are predominantly conducted in the Carpathians (277) and the Carpathian Foredeep (96), followed by Holy Cross Mts (129), Ukraine (remarkable number of 120 papers!) and Sudetes (116).

\section{FINAL REMARKS}

1. The progressively successful fields in Polish sedimentary research over the past 20 years include in first order large-scale palaeogeographic and lithofacies analyses in a broad geotectonic framework (by Golonka), and also tectonic-regional aspects of basin analysis, developed by several research groups 
in Cracow, Warsaw and Wrocław, in agreement with one of the leading research frontier in global science.

2. Ecological and integrative stratigraphic-event characteristics of sedimentary successions are another well-known Polish areas of expertise, the best exemplified by flysch ichnology (Uchman) and Devonian studies at University of Silesia.

3. Sedimentary geochemistry is still in infancy in Poland, despite a big progress in last years (in particular organic topics Marynowski).

4. The dominance of Cracow geological school is obvious, rooted in a long-lasting tradition of mostly Carpathian studies at Jagiellonian University since XIX century, even if the sedimentary research is well advanced in many other institutions in Po- land as well. For example, a newly emerging Polish specialty in tsunami hazard studies (Szczuciński) is notably located at Adam Mickiewicz University.

5. Carpathian and post-Paleozoic stratigraphic-sedimentological themes were continuously the most popular, while an evolution toward effective cooperation in mostly international groups (also outside of Poland, especially in Ukraine) appears to be the most significant tendency in modern Polish geosciences.

Acknowledgments. I thank the journal reviewers, A. Wysocka and M. Narkiewicz, for constructive comments and remarks improving the manuscript.

\section{REFERENCES*}

Benzerara, K., Menguy, N., López-García, P., Yoon, T.-H., Kaźmierczak, J., Tyliszczak, T., Guyot, F.A, Brown., G.E., 2006. Nanoscale detection of organic signatures in carbonate microbialites. Proceedings of the National Academy of Sciences of the United States of America, 103: 9440-9445.

Bertling, M., Braddy, S.J., Bromley, R.G., Demathieu, G.R., Genise, J., Mikuláš, R., Nielsen, J.K., Nielsen, K.S.S., Rindsberg, A.K., Schlirf, M., Uchman, A., 2006. Names for trace fossils: a uniform approach. Lethaia, 39: 265-286.

Budzinski, H., Jones, I., Bellocq, J., Piérard, C., Garrigues, P., 1997. Evaluation of sediment contamination by polycyclic aromatic hydrocarbons in the Gironde estuary. Marine Chemistry, 58: 85-97.

Cymerman, Z., Piasecki, M.A.J., Seston, R., 1997. Terranes and terrane boundaries in the Sudetes, northeast Bohemian Massif. Geological Magazine, 134: 717-725.

Drabek, A., 2010. Bibliometryczna analiza czasopism naukowych w dziedzinie nauk społecznych (in Polish). Duet, Toruń.

Dubińska, E., Bylina, P., Kozłowski, A., Dörr, W., Nejbert, K., Schastok, J., Kulicki, C., 2004. U-Pb dating of serpentinization: Hydrothermal zircon from a metasomatic rodingite shell (Sudetic ophiolite, SW Poland). Chemical Geology, 203: 183-203.

Dupraz, C., Reid, R.P., Braissant, O., Dechoc, A.W., Norman, R.S., Visscher, P.T., 2009. Processes of carbonate precipitation in modern microbial mats. Earth-Science Reviews, 96: 141-162.

Dzułyński, S., Ksią kiewicz, M., Kuenen, P.H., 1959. Turbidites in flysch of the Polish Carpathian Mountains. Bulletin of the Geological Society of America, 70: 1089-1118.

Franck, G., 1999. Scientific communication - a vanity fair? Science, 286: 53,55 .

Garfield, E., 1979. Citation indexing: its Theory and Application in Science, Technology, and Humanities. John Wiley and Sons, New York.

Goto, K., Chagué-Goff, C., Fujino, S., Goff, J., Jaffe, B., Nishimura, Y., Richmond, B., Sugawara, D., Szczuciński, W., Tappin, D.R., Witter, R.C., Yulianto, E., 2011. New insights of tsunami hazard from the 2011 Tohoku-oki event. Marine Geology, 290: 46-50.

Guterch, A., Grad, M., Thybo, H., Keller, G.R., Czuba, W., Gaczyński, E., Grad, M., Guterch, A., Janik, T., Materzok, R., Środa, P., Wilde-Piórko, M., Jensen, S.L., Thybo, H., Harder, S., Keller, G.R., Miller, K.C., Schulze, A., Schuster, K., Komminaho, K., Luosto, U., Tiira, T., Yliniemi, J., Motuza, G., Nasedkin, V., Lund, C.E., 1999. POLONAISE ' 97 - an international seismic experiment between Precambrian and Variscan Europe in Poland. Tectonophysics, 314: 101-121.
Joachimski, M.M., Ostertag-Henning, C., Pancost, R.D., Strauss, H., Freeman, K.H., Littke, R., Sinninghe Damsté, J.S., Racki, G., 2001. Water column anoxia, enhanced productivity and concomitant changes in $\delta^{13} \mathrm{C}$ and $\delta^{34} S$ across the Frasnian-Famennian boundary (Kowala - Holy Cross Mountains/Poland). Chemical Geology, 175: 109-131.

Kennedy, W.J., Walaszczyk, I., Cobban, W.A., 2000. Pueblo, Colorado, USA, candidate Global Boundary Stratotype Section and Point for the base of the Turonian Stage of the Cretaceous, and for the base of the Middle Turonian Substage, with a revision of the Inoceramidae (Bivalvia). Acta Geologica Polonica, 50: 295-334.

Krajewski, K.P., Van Cappellen, P., Trichet, J., Kuhn, O., Lucas, J., Martin-Algarra, A., Prévot, L., Tewari, V.C., Gaspar, L., Knight, R.I., Lamboy, M., 1994. Biological processes and apatite formation in sedimentary environments. Eclogae Geologicae Helvetiae, 87: 701-745.

Kryza, R., Pin, C., Vielzeuf, D., 1996. High-pressure granulites from the Sudetes (south-west Poland): evidence of crustal subduction and collisional thickening in the Variscan Belt. Journal of Metamorphic Geology, 14: 531-546.

Litt, T., Brauer, A., Goslar, T., Merkt, J., Balaga, K., Müller, H. Ralska-Jasiewiczowa, M., Stebich, M., Negendank, J.F.W., 2001. Correlation and synchronisation of Late glacial continental sequences in northern central Europe based on annually laminated lacustrine sediments. Quaternary Science Reviews, 20: 1233-1249.

Loska, K., Wiechuła, D., 2003. Application of principal component analysis for the estimation of source of heavy metal contamination in surface sediments from the Rybnik Reservoir. Chemosphere, 51: 723-733.

Machel, H.G., 2001. Bacterial and thermochemical sulfate reduction in diagenetic settings - old and new insights. Sedimentary Geology, 140: 143-175.

Macklin, M.G., Benito, G., Gregory, K.J., Johnstone, E., Lewin, J., Michczyńska, D.J., Soja, R., Starkel, L., Thorndycraft, V.R., 2006. Past hydrological events reflected in the Holocene fluvial record of Europe. Catena, 66: 145-154.

Marszakowa-Szajkiewicz, I., 2009. Badania ilościowe nauki. Podejście bibliometryczne i webometryczne (in Polish). Uniwersytet im. Adama Mickiewicza, Poznań.

Marynowski, L., Simoneit, B.R.T., 2009. Widespread Upper Triassic to Lower Jurassic wildfire records from Poland: evidence from charcoal and pyrolytic polycyclic aromatic hydrocarbons. Palaios, 24: 785-798.

Mazur, S., Aleksandrowski, P., Kryza, R., Oberc-Dziedzic, T., 2006. The Variscan Orogen in Poland. Geological Quarterly, $\mathbf{5 0}$ (1): 89-118. 
Mench, M., Lepp, N., Bert, V., Schwitzguébel, J.-P., Gawroński, S.W., Schröder, P., Vangronsveld, J., 2010. Successes and limitations of phytotechnologies at field scale: outcomes, assessment and outlook from COST Action 859. Journal of Soils and Sediments, 10: 1039-1070.

Miall, A.D., 1996. The geology of fluvial deposits sedimentary facies, basin analysis, and petroleum geology. Springer, Berlin.

Moed, H.F., 2005. Citation analysis in research evaluation. Springer, Berlin.

Middleton, G.V., 1974. Citation patterns of papers published in the Journal of Sedimentary Petrology. Journal of Sedimentary Petrology, 44: 3-6.

Nowak, P., 2008. Bibliometria webometria (in Polish). Podstawy. Wybrane zastosowania, 2nd edit. Wydaw. Nauk. UAM, Poznań.

Pilkey, O.H., Wilcox, M., 1981. Citation analysis of principal sedimentology journals. Journal of Sedimentary Petrology, 50 : 1044-1045.

Racki, G., 2002. What is hot in sedimentary research over the millennium crossroad? Acta Geologica Polonica, 52: 577-584.

Radwański, A., Roniewicz, P., 1963. Upper Cambrian trilobite ichnocoenosis from Wielka Wiśniówka (Holy Cross Mountains, Poland). Acta Palaeontologica Polonica, 8: 259-280.

Ramsey, C.B., 2008. Deposition models for chronological records. Quaternary Science Reviews, 27: 42-60.
Rinterknecht, V.R., Clark, P.U., Raisbeck, G.M., Yiou, F., Bitinas, A., Brook, E.J., Marks, L., Zelčs, V., Lunkka, J.P., Pavlovskaya, I., Piotrowski, J.A., Raukas, A., 2006. The last deglaciation of the southeastern sector of the Scandinavian ice sheet. Science, 311: 1449-1452.

Schwechheimer, H., Winterhager, M., 1999. Highly dynamic specialities in climate research. Scientometrics, 44: 547-560.

Singhvi, A.K., Bluszcz, A., Bateman, M.D., Someshwar Rao, M., 2001. Luminescence dating of loess-palaeosol sequences and coversands: aspects and palaeoclimatic implications. Earth-Science Reviews, 54: 193-211.

Środoń, J., 1999. Nature of mixed-layer clays and mechanisms of their formation and alteration. Annual Review of Earth and Planetary Sciences, 27: 19-53.

Szczuciński, W., 2012. The post-depositional changes of the onshore 2004 tsunami deposits on the Andaman Sea coast of Thailand. Natural Hazards, 60: 115-133.

Szulczewski, M., Belka, Z., Skompski, S., 1996. The drowning of a carbonate platform: an example from the Devonian-Carboniferous of the southwestern Holy Cross Mountains, Poland. Sedimentary Geology, 106: 21-49. 


\section{APPENDIX 1}

\section{Results of the rare earth element (REE) composition analyses in the samples studied}

\begin{tabular}{|c|c|c|c|c|c|c|c|c|c|c|c|c|c|c|c|c|c|c|c|}
\hline \multirow{2}{*}{ No. } & \multirow{2}{*}{$\begin{array}{c}\text { Laboratory } \\
\text { No. }\end{array}$} & \multirow{2}{*}{ Sample } & Sc & $Y$ & $\mathrm{La}$ & $\mathrm{Ce}$ & $\mathrm{Pr}$ & $\mathrm{Nd}$ & $\mathrm{Sm}$ & $\mathrm{Eu}$ & $\mathrm{Gd}$ & $\mathrm{Tb}$ & Dy & $\mathrm{Ho}$ & $\mathrm{Er}$ & $\mathrm{Tm}$ & $\mathrm{Yb}$ & Lu & Th \\
\hline & & & \multicolumn{17}{|c|}{$\mathrm{ppm}$} \\
\hline 1. & $10 / 13 / 30$ & & 15.0 & 21.2 & 34.8 & 72.8 & 8.6 & 33.3 & 6.47 & 1.33 & 5.35 & 0.75 & 4.29 & 0.81 & 2.42 & 0.36 & 2.31 & 0.35 & 12.89 \\
\hline 2. & $10 / 13 / 31$ & $\mathrm{Nk} / 178.4$ & 11.8 & 81.1 & 441.6 & 1131.9 & 128.8 & 499.6 & 97.45 & 19.09 & 70.77 & 8.28 & 33.44 & 4.29 & 8.75 & 0.92 & 4.68 & 0.60 & 12.37 \\
\hline 3. & $10 / 13 / 32$ & $\mathrm{Nk} / 167.8$ & 23.2 & 10.8 & 16.1 & 33.8 & 4.1 & 15.3 & 2.98 & 0.54 & 2.16 & 0.35 & 2.12 & 0.44 & 1.33 & 0.21 & 1.59 & 0.24 & 20.44 \\
\hline 4. & $10 / 13 / 33$ & $\mathrm{Nk} / 162.3$ & 24.1 & 23.0 & 4.8 & 8.8 & 0.9 & 3.5 & 1.11 & 0.35 & 2.17 & 0.50 & 3.88 & 0.85 & 2.65 & 0.43 & 3.68 & 0.44 & 22.37 \\
\hline 5. & $10 / 13 / 34$ & & 16.6 & 25.9 & 42.1 & 78.9 & 8.2 & 28.6 & 5.00 & 1.00 & 4.49 & 0.78 & 4.86 & 1.02 & 3.08 & 0.48 & 3.25 & 0.48 & 17.45 \\
\hline 6. & $10 / 13 / 35$ & & 11.7 & 23.0 & 40.9 & 101.0 & 10.4 & 41.4 & 8.07 & 1.47 & 5.87 & 0.84 & 4.62 & 0.91 & 2.84 & 0.43 & 2.92 & 0.46 & 13.17 \\
\hline 7. & $10 / 13 / 36$ & & 23.3 & 25.5 & 52.8 & 106.0 & 11.7 & 43.2 & 7.86 & 1.55 & 5.60 & 0.85 & 5.07 & 1.02 & 3.00 & 0.44 & 2.94 & 0.44 & 21.37 \\
\hline 8. & $5 / 15 / 24$ & & 15.8 & 44.0 & 144.0 & 275.6 & 29.2 & 117.8 & 23.26 & 4.90 & 18.72 & 2.36 & 11.77 & 2.08 & 5.69 & 0.72 & 4.65 & 0.68 & 12.13 \\
\hline 9. & $10 / 13 / 37$ & $\mathrm{~K} / 1480.3$ & 14.0 & 18.5 & 35.1 & 76.1 & 8.5 & 32.8 & 6.54 & 1.26 & 4.69 & 0.66 & 3.73 & 0.73 & 2.16 & 0.32 & 2.23 & 0.34 & 14.39 \\
\hline 10. & $5 / 15 / 23$ & $\mathrm{~K} / 1465.2$ & 14.4 & 16.3 & 45.1 & 100.6 & 10.0 & 35.6 & 5.67 & 1.11 & 3.93 & 0.58 & 3.48 & 0.71 & 2.27 & 0.34 & 2.41 & 0.39 & 21.43 \\
\hline 11. & $5 / 15 / 25$ & $\mathrm{~K} / 1464.3$ & 14.2 & 18.9 & 68.2 & 161.4 & 16.3 & 57.1 & 9.30 & 1.61 & 6.11 & 0.79 & 4.60 & 0.95 & 3.12 & 0.45 & 3.17 & 0.52 & 22.06 \\
\hline 12. & $10 / 13 / 38$ & $\mathrm{~K} / 1463.7$ & 23.7 & 39.5 & 114.7 & 234.4 & 25.2 & 86.9 & 13.83 & 2.32 & 8.76 & 1.32 & 7.80 & 1.59 & 5.17 & 0.83 & 5.78 & 0.91 & 51.89 \\
\hline 13. & $5 / 15 / 26$ & $\mathrm{~K} / 1462.3$ & 11.9 & 20.2 & 60.5 & 133.9 & 13.1 & 45.2 & 7.81 & 1.41 & 5.86 & 0.78 & 4.37 & 0.86 & 2.62 & 0.36 & 2.37 & 0.37 & 33.61 \\
\hline 14. & $5 / 15 / 14$ & $\mathrm{M} / 1130.0$ & 10.2 & 30.9 & 42.5 & 97.1 & 10.9 & 41.0 & 8.11 & 1.20 & 6.74 & 1.02 & 6.00 & 1.19 & 3.53 & 0.51 & 3.33 & 0.52 & 23.40 \\
\hline 15. & $5 / 15 / 15$ & $\mathrm{M} / 700.5$ & 7.9 & 16.1 & 31.6 & 69.5 & 7.5 & 28.0 & 5.21 & 0.83 & 4.02 & 0.58 & 3.23 & 0.63 & 1.85 & 0.26 & 1.71 & 0.26 & 14.00 \\
\hline 16. & $10 / 13 / 39$ & $\mathrm{BL} / 185.5$ & 8.9 & 14.5 & 28.8 & 58.5 & 6.7 & 25.3 & 4.64 & 0.76 & 3.48 & 0.53 & 2.97 & 0.56 & 1.62 & 0.24 & 1.61 & 0.25 & 10.99 \\
\hline 17. & $10 / 13 / 40$ & $\mathrm{BL} / 162.0$ & 11.8 & 20.7 & 32.7 & 76.0 & 8.4 & 33.0 & 6.47 & 1.28 & 5.23 & 0.76 & 4.27 & 0.82 & 2.42 & 0.36 & 2.33 & 0.36 & 12.58 \\
\hline 18. & $10 / 13 / 41$ & $\mathrm{BL} / 159.0$ & 19.1 & 25.0 & 46.0 & 89.8 & 10.3 & 39.3 & 7.41 & 1.50 & 5.86 & 0.88 & 4.99 & 0.97 & 2.87 & 0.42 & 2.68 & 0.41 & 16.85 \\
\hline 19. & $5 / 15 / 27$ & GW/815.0 & 17.7 & 21.3 & 43.8 & 90.5 & 10.2 & 37.7 & 7.00 & 1.50 & 5.74 & 0.80 & 4.57 & 0.89 & 2.66 & 0.36 & 2.33 & 0.35 & 12.92 \\
\hline
\end{tabular}

\begin{tabular}{|c|c|c|c|c|c|c|c|c|c|c|c|c|c|c|c|c|c|}
\hline PAAS ${ }^{*}$ & 16 & 27 & 38.2 & 79.6 & 8.83 & 33.90 & 1.08 & 5.55 & 4.66 & 0.77 & 4.68 & 0.99 & 2.85 & 0.41 & 2.82 & 0.43 & 14.60 \\
\hline chondrite* & & & 0.367 & 0.957 & 0.137 & 0.711 & 0.231 & 0.087 & 0.306 & 0.058 & 0.381 & 0.0851 & 0.249 & 0.0356 & 0.248 & 0.0381 & \\
\hline
\end{tabular}

Dark red - Norian, pink - Rhaetian, dark blue - Hettangian, blue - Sinemurian, light blue - Pliensbachian, green - Toarcian

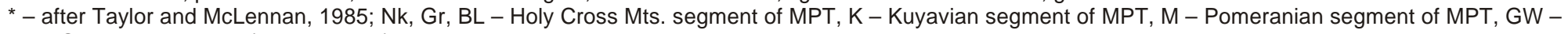
Fore-Sudetic Monocline (northern part) 